\title{
Thermal Decomposition and Kinetic Studies of Pyrolysis of Spirulina platensis Residue
}

\author{
Siti Jamilatun ${ }^{\mathrm{a}, \mathrm{b}}$, Budhijanto ${ }^{\mathrm{b}}$ Rochmadi $^{\mathrm{b}}$ and Arief Budiman ${ }^{\mathrm{b}, \mathrm{c}, *}$ \\ ${ }^{a}$ Chemical Engineering Department, Ahmad Dahlan University, Jl. Kapas 9, Yogyakarta 55166, Indonesia \\ ${ }^{b}$ Chemical Engineering Department, Gadjah Mada University, Jl. Grafika 2, Yogyakarta 55284, Indonesia \\ ${ }^{c}$ Center for Energy Studies, Gadjah Mada University, Sekip K1A, Yogyakarta 55281, Indonesia
}

\begin{abstract}
Analysis of thermal decomposition and pyrolisis reaction kinetics of Spirulina platensis residue (SPR) was performed using Thermogravimetric Analyzer. Thermal decomposition was conducted with the heating rate of 10, 20, 30, 40 and $50^{\circ} \mathrm{C} / \mathrm{min}$ from 30 to $1000^{\circ} \mathrm{C}$. Thermogravimetric (TG), Differential Thermal Gravimetric (DTG), and Differential Thermal Analysis (DTA) curves were then obtained. Each of the curves was divided into 3 stages. In Stage I, water vapor was released in endothermic condition. Pyrolysis occurred in exothermic condition in Stage II, which was divided into two zones according to the weight loss rate, namely zone 1 and zone 2. It was found that gasification occurred in Stage III in endothermic condition. The heat requirement and heat release on thermal decomposition of SPR are described by DTA curve, where 3 peaks were obtained for heating rate 10,20 and $30^{\circ} \mathrm{C} / \mathrm{min}$ and 2 peaks for 40 and $50^{\circ} \mathrm{C} / \mathrm{min}$, all peaks present in Zone 2 . As for the DTG curve, 2 peaks were obtained in Zone 1 for similar heating rates variation. On the other hand, thermal decomposition of proteins and carbohydrates is indicated by the presence of peaks on the DTG curve, where lignin decomposition do not occur due to the low lipid content of SPR $(0.01 \mathrm{wt} \%)$. The experiment results and calculations using one-step global model successfully showed that the activation energy (Ea) for the heating rate of $10,20,30,40$ and $50^{\circ} \mathrm{C} / \mathrm{min}$ for zone 1 were $35.455,41.102,45.702,47.892$ and $47.562 \mathrm{KJ} / \mathrm{mol}$, respectively, and for zone 2 were $0.0001428,0.0001240,0.0000179,0.0000100$ and $0.0000096 \mathrm{KJ} / \mathrm{mol}$, respectively.
\end{abstract}

Keywords: Spirulina platensis residue (SPR), Pyrolysis, Thermal decomposition, Peak, Activation energy.

Article History: Received June 15 th 2017; Received in revised form August 12 ${ }^{\text {th }}$ 2017; Accepted August 20 th 2017; Available online How to Cite This Article: Jamilatun, S., Budhijanto, Rochmadi, and Budiman, A. (2017) Thermal Decomposition and Kinetic Studies of Pyrolysis of Spirulina platensis Residue, International Journal of Renewable Energy Development 6(3), 193-201. https://doi.org/10.14710/ijred.6.3.193-201

\section{Introduction}

The source of energy derived from crop and noncrop plants of the first and second generations of biomass not only competes with feedstock but also requires a large cultivation area (Chaiwong et al. 2013; Dragone et al. 2010). This has put the interests in the third generation of biomass as the alternative source of energy, including microalgae, which are believed to be the future energy source. With an efficient land for cultivation, it is possible to produce $40-80$ ton of dry microalgae per hectare per annum (Wijffels, 2010). In addition, microalgae can grow in open pond as well as wastewater with a high $\mathrm{CO}_{2}$ requirement (Hadiyanto et al. 2012) hence its cultivation can be employed as an alternative to rapidly reduce the greenhouse gasses emission from the proliferating industrial operation (Hadiyanto et al. 2013; Sunarno et al. 2017).

Energy source from microalgae which is processed into biodiesel usually contains lipid in a high concentration of lipids, such as Scenedesmus dimorphus (16-40 wt\%), Chlorella vulgaris (14-49.5 wt\%), Prymnesium parvum (22-39 wt\%), and Nannochloropsis oceanica (24.8 wt\%) (Suganya et al. 2016). After the lipid content is extracted, the solid waste with a very low lipid content (0.01 wt\%) is obtained. An inappropriate disposal of this waste will contaminate the environment. Moreover, the waste cannot be used as animal feed due to its remaining methanol content after extraction (Chisti 2008). The waste also still contains protein and carbohydrate at an

\footnotetext{
* Corresponding author: abudiman@ugm.ac.id
} 
adequately high level (Ceylan et al. 2014), therefore exhibiting a great potential to process thermochemically into a new source of energy (Ananda et al. 2016).

The lipid content in the solid waste of microalgae extraction, such as Chlorella vulgaris residue (5.71 wt. $\%)$, Spirulina platensis residue (0.01 wt \%), Chlorella sorokiniana CY1 residue (9.9 wt. \%), and Nannochloropsis oceanica residue is notably low. On the other hand, their high protein and carbohydrate content offers an attractive potential as a raw material of bio-oil (Chen et al., 2015). Bio-oil has attracted immense attractions due to its high calorific value such as from Chlorella vulgaris residue (24.57-35.10 $\mathrm{MJ} / \mathrm{kg})$, Spirulina platensis residue (20.46 - 33.62 $\mathrm{MJ} / \mathrm{kg})$, Chlorella sorokiniana CY1 residue (20.24 $\mathrm{MJ} / \mathrm{kg}$ ), and Nannochloropsis oceanica residue (32.33-39 MJ/kg) (Chen et al. 2015). As a comparison, these calorific values are higher than bio-oil produced from lignocellulose such as coconut shell $(21.28 \mathrm{MJ} / \mathrm{kg})$ and sugarcane bagasse (El-Sayed et al. 2014).

So far, many studies have been done to produce biooil from microalgae using various technologies. Among them, thermochemistry by pyrolysis is simpler and can be performed at atmospheric pressure. Moreover, unlike liquefaction, pyrolysis does not require solvents (Lia et al. 2013; Widiyannita et al. 2015). The bio-oil production in industrial scale needs to be evaluated in regards to the process feasibility, especially for reactor design, hence requiring kinetic data (Pratama et al. 2014; Ojolo et al. 2013; Daniyanto et al. 2016) and decomposition characteristics (Hu et al. 2015). Previously, Agrawal and Chakraborty (2013) reported that in the pyrolysis of Chlorella vulgaris, the activation energy of protein and carbohydrate decomposition in Stage II in Zone I is $51 \mathrm{~kJ} / \mathrm{kg}$, lower than the activation energy of lipid $(64 \mathrm{~kJ} / \mathrm{kg})$ that occurs in Zone 2.

Thermal Gravimetric (TG), Differential Thermal Gravimetric (DTG), and Differential Thermal Analysis (DTA) methods are very important in investigating the kinetics and thermal decomposition characteristics of biomass in a thermochemical conversion process (Wang et al. 2016). These methods have a high accuracy to study the degradation conditions in kinetic regime (Li et al. 2016). The decomposition mechanism and kinetic model are predicted and tested with data obtained from experiments (Wicakso et al. 2017). Therefore, this study aims to investigate the thermal decomposition characteristics and kinetics in pyrolysis process of Spirulina platensis residue (SPR) using a distribution model of activation energy in various heating rates with the one-step global model.

\section{Materials and Methods}

\subsection{Materials}

The raw material used in this study was solid waste from SPR which was dried using a microwave at $60^{\circ} \mathrm{C}$ until a constant weight was obtained. The dried solid was then extruded until a homogenous size of $125 \mu \mathrm{m}$. Ultimate analysis, protein, lipid, and carbohydrate content analysis, and calculation of the caloric value of the waste from SPR were performed in Research and Development of Energy and Mineral Resources, Center for Research and Development of Mineral and Coal Technology, Bandung.

\subsection{Experimental methods}

Thermal decomposition and pyrolisis kinetics of SPR were studied by Thermogravimetric Analyzer using Perkin Elmer Pyric Diamond TG-DTA. The SPR sample for each experiment, $3.536-11.933 \mathrm{mg}$ in weight, was fed into alumina crucible which was operated in non-isothermal condition. Heating was done in a range of $30-1000^{\circ} \mathrm{C}$ with the heating rate of $10,20,30,40$ and $50^{\circ} \mathrm{C} / \mathrm{min}$ while exhaled with pure nitrogen gas at a rate of $20 \mathrm{~mL} / \mathrm{min}$. The temperature was kept constant for 5 minutes when reached 120 and $600^{\circ} \mathrm{C}$ to ensure complete water vaporisation and pyrolisis.

\subsection{Kinetic modeling}

The proposed kinetic model was the one-step global model, assuming that the weight change of the sample was observable. This model also assumes pyrolysis as a one-step order 1 reaction, where organic fuel decomposes into volatile matter and char with a constant char production (Equation 1) (Prakash and Karunanithi 2008).

Biomass $\rightarrow$ Volatile Matter + Char

The sample was pyrolyzed with Thermogravimetric Analyzer in non-isothermal condition. The weight change of the sample was noted. The change of conversion and degradation in regards to time, $\mathrm{dX} / \mathrm{dt}$, depends on the rate of reaction constants which are influenced by temperature $[\mathrm{k}(\mathrm{T})]$ and conversion $[\mathrm{f}(\mathrm{X})]$, expressed as:

$$
\frac{d X}{d t}=k(T) \cdot f(X)
$$

where:

- $\mathrm{X}$ is conversion,

- $\mathrm{t}$ is time (minute),

- $\mathrm{T}$ is temperature $(\mathrm{K})$.

The rate of reaction constants, $k$, are calculated using the Arrhenius equation:

$$
k=A \cdot \exp \left(\frac{-E a}{R T}\right)
$$

where:

- A is Arrhenius factor,

- Ea is activation energy, 
- $\quad \mathrm{R}$ is universal gas constant (J/mole.K).

The function $f(X)$ is expressed as:

$$
f(X)=(1-X)^{n}
$$

where $\mathrm{n}$ is the order of reaction, in this case, is assumed to be one. The SPR conversion (X) is calculated with Ojolo et al. (2013):

$$
X=\frac{m_{0}-m_{t}}{m_{t}-m_{\sim}}
$$

where:

- $\mathrm{m}_{\mathrm{o}}$ is the initial weight of SPR,

- $\mathrm{m}_{\mathrm{t}}$ is the weight of SPR at time $\mathrm{t}$,

- $\mathrm{m}_{\infty}$ is the final weight of SPR at the end of the reaction.

Combining Equation (1-4) results in:

$$
\frac{d X}{d t}=A \cdot \exp \left(\frac{-E a}{R T}\right)(1-X)^{n}
$$

$T=T_{O}+\beta(t)$

$\beta=\frac{d T}{d t}$

where $B$ is the heating rate $\left({ }^{\circ} \mathrm{C} / \mathrm{s}\right)$.

The value of A and Ea are calculated using the least squares method. Sum of squared errors (SSE) is calculated using:

$$
S S E=\sum\left[(X)_{\text {calculated }}-(X)_{\text {data }}\right]^{2}
$$

\section{Results and Discussion}

\subsection{Characterization of SPR}

The results of the ultimate analysis, protein, lipids, carbohydrates analysis and calculated higher heating value (HHV) of SPR are presented in Table 1. To investigate the potential of SPR as a promising energy source, each of these values is compared with Chlorella vulgaris with a high lipid content that has been extensively studied as a future source of energy.

The characteristics of SPR are similar to those of Chlorella vulgaris, particularly in C content (41.36$42.51 \mathrm{wt} \%), \mathrm{N}$ content (6.66-7.17 wt\%) and $\mathrm{H}$ content (6.60-6.77 wt\%), but the content of $\mathrm{O}$ are slightly different. The O content in SPR (35.33\%) is higher than in Chlorella vulgaris (27.95 wt\%). In addition, the HHV of SPR is also higher $(18.21 \mathrm{MJ} / \mathrm{kg})$ when compared with Chlorella vulgaris $(16.80 \mathrm{MJ} / \mathrm{kg})$. This can be ascribed to the different $\mathrm{C}$ and $\mathrm{O}$ content. A larger $\mathrm{C}$ content and a smaller $\mathrm{O}$ content of the biomass will result in a greater $\mathrm{HHV}$.
Table 1

The main characteristics of the SPR and Chlorella vulgaris (Ananda et al. 2016)

\begin{tabular}{lcc}
\hline Component & SPR $^{\mathrm{a}}$ & $\begin{array}{c}\text { Chlorella } \\
\text { vulgaris }\end{array}$ \\
\hline Elemental analysis (wt\%) & & \\
& & \\
Carbon & 41.36 & 42.51 \\
Hydrogen & 6.60 & 6.77 \\
Nitrogen & 7.17 & 6.64 \\
Oxygen & 35.33 & 27.95 \\
Higher heating value, & 18.21 & 18.80 \\
HHV(MJ/kg) & & \\
Composition (dry-ash free, wt\%) & & \\
$\quad$ Protein & 49.60 & 41.51 \\
$\quad$ Lipid & 0.01 & 15.71 \\
$\quad$ Carbohydrate & 25.60 & 20.99 \\
\hline a. This experiment & &
\end{tabular}

\subsection{Thermogravimetric analysis}

\subsubsection{TG curves}

The weight loss from thermal decomposition of SPR with $10,20,30,40$ and $50^{\circ} \mathrm{C} / \mathrm{min}$ heating rates $(\mathrm{HR})$, exhaled with $20 \mathrm{~mL} \mathrm{~min}^{-1}$ pure $\mathrm{N}_{2}$ was studied. The TG curve for the heating rate of $20^{\circ} \mathrm{C} / \mathrm{min}$ is shown in Figure 1. To understand the occurring process in the picture, the curve is divided into three stages. Stage I is water evaporation $\left(30-230^{\circ} \mathrm{C}\right)$, Stage II $\left(231-615^{\circ} \mathrm{C}\right)$ is pyrolysis, and Stage III is gasification $\left(616-1000^{\circ} \mathrm{C}\right)$. The stage temperature obtained from TG curve is affected by the type and composition of biomass. For example, stage temperatures for Chlorella vulgaris with a heating rate $10^{\circ} \mathrm{C} / \mathrm{min}$ are $50-180^{\circ} \mathrm{C}$ in Stage I, $181-615^{\circ} \mathrm{C}$ in Stage II, and $616-800^{\circ} \mathrm{C}$ in Stage III (Wang et al. 2016). In SPR pyrolysis, it can be seen that in Stage I for temperature $120-200^{\circ} \mathrm{C}$, at $10.45-13.5$ minutes, the curve forms a flat line because at $120^{\circ} \mathrm{C}$ the temperature is kept constant for 5 minutes. This is also the case at $600^{\circ} \mathrm{C}$.

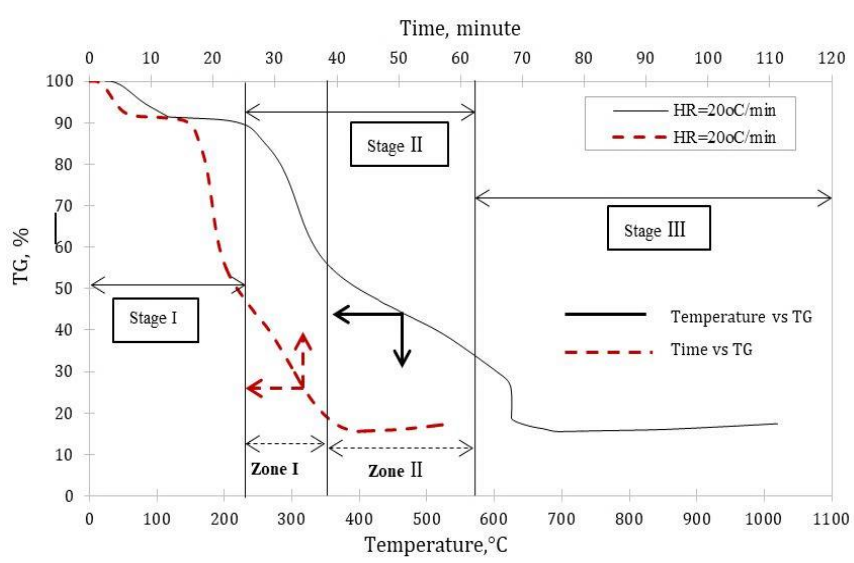

Fig. 1 Thermal decomposition of the SPR at heating rate $20^{\circ} \mathrm{C} / \mathrm{min}$

The thermal decomposition for the overall heating rate $10,20,30,40$ and $50^{\circ} \mathrm{C} / \mathrm{min}$ is presented in Figure 2. As can be seen in Fig. 2, though the initial 
Citation: Jamilatun, S., Budhijanto, Rochmadi, and Budiman, A. (2017) Thermal Decomposition and Kinetic Studies of Pyrolysis of Spirulina platensis Residue. Int. Journal of Renewable Energy Development, 6(3), 193-201, https://doi.org/10.14710/ijred.6.3.193-201

$\mathrm{P}$ a g e | 196

temperature of pyrolysis begins to increase as the heating rate increases, the final temperature of the pyrolysis is not affected by the heating rate. This is due to the typical weight loss characteristics that will occur in each heating rate. The thermal decomposition of proteins and carbohydrates in the SPR is very complex, where there are simultaneous reactions between dehydration, depolymerization, re-polymerization, fragmentation, rearrangement and condensation. In case the time required for pyrolysis is greatly influenced by the magnitude of the heating rate, a greater heating rate results in a shorter pyrolysis time. The distribution of stage temperature range and time required for pyrolysis with heating rate 10, 20, 30, 40 and $50^{\circ} \mathrm{C} / \mathrm{min}$ is listed in Table 2 .

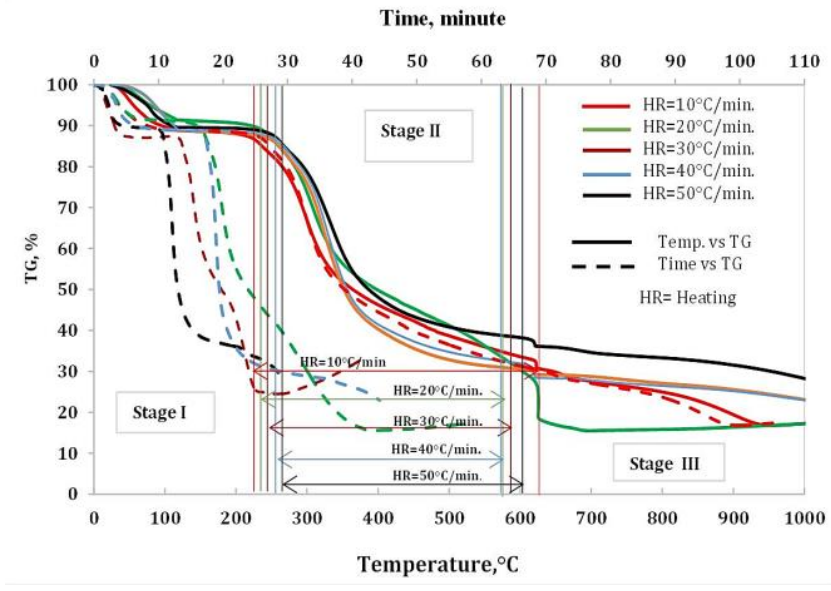

Fig. 2 Thermal decomposition at different heating rates

Table 2

Distribution of stage and time required for SPR pyrolysis at various heating rates

\begin{tabular}{lccccc}
\hline Heating rate, ${ }^{\circ} \mathbf{C} / \mathbf{m i n}$ & $\mathbf{1 0}$ & $\mathbf{2 0}$ & $\mathbf{3 0}$ & $\mathbf{4 0}$ & $\mathbf{5 0}$ \\
\hline Stage I, ${ }^{\circ} \mathrm{C}$ (Drying) & $30-220$ & $30-230$ & $30-240$ & $30-250$ & $30-260$ \\
Stage II, ${ }^{\circ} \mathrm{C}$ (Pyrolysis) & $221-615$ & $231-570$ & $241-585$ & $251-570$ & $261-600$ \\
Stage III, ${ }^{\circ} \mathrm{C}$ (Gasification) & $616-1000$ & $571-1000$ & $586-1000$ & $571-1000$ & $601-1000$ \\
Pyrolysis residence time, min & 36.283 & 15.08 & 10.15 & 7.50 & 5.97 \\
\hline
\end{tabular}

\subsubsection{TG-DTA curves}

Figure 3 depicts the TG-DTA curve at the heating rate $20^{\circ} \mathrm{C} / \mathrm{min}$. As it can be seen from Fig. 3 that the endothermic process occurs in Stage I with 2 low peaks at 79.37 and $116.34^{\circ} \mathrm{C}$, with the heat requirement of 25.06 and 6.40 MW, respectively. Pyrolysis in Stage II is divided into 2 zones, i.e. zone 1 at $230-350^{\circ} \mathrm{C}$ and Zone 2 at $351-570^{\circ} \mathrm{C}$. At this stage pyrolysis occurs exothermically with 3 strong peaks in Zone 2 at 378.32 , 462.69 and $547.84^{\circ} \mathrm{C}$, releasing $26.45,40.45$, and 47.64 MW of heat, respectively. At the top of the peak, the maximum heat dissipation occurs due to the decomposition of proteins and carbohydrates, where $\mathrm{O}$ $\mathrm{O}, \mathrm{N}-\mathrm{O}, \mathrm{C}-\mathrm{N}, \mathrm{C}-\mathrm{C}, \mathrm{C}-\mathrm{O}, \mathrm{N}-\mathrm{H}, \mathrm{C}-\mathrm{H}, \mathrm{N}=\mathrm{N}, \mathrm{H}=\mathrm{H}, \mathrm{O}-\mathrm{H}$, $\mathrm{O}=\mathrm{O}, \mathrm{C}=\mathrm{C}, \mathrm{C}=\mathrm{N}$, and $\mathrm{C}=\mathrm{O}$ bonds are terminated. Since the SPR sample did not contain lipids, lipid decomposition did not occur. Following the pyrolysis is the gasification in Stage III occurring in endothermic condition, with 2 peaks at 632.64 and $689.16^{\circ} \mathrm{C}$ and heat requirement of 4.02 and $28.88 \mathrm{MW}$, respectively. As comparison, thermal decomposition of Chlorella vulgaris with $10^{\circ} \mathrm{C} / \mathrm{min}$ heating rate produces one low endothermic peak in Stage I, one strong exothermic peak in Stage II, and one strong peak in Stage III (Wang et al. 2016). Differences in the number of peaks between SPR and Chlorella vulgaris can be due to differences in heating rate as well as the $\mathrm{O}$, protein, carbohydrate and lipid content. It should be noted that the heat requirement for gasification will increase to 74 $\mathrm{MW}$ as the temperature rises up to $1000^{\circ} \mathrm{C}$.

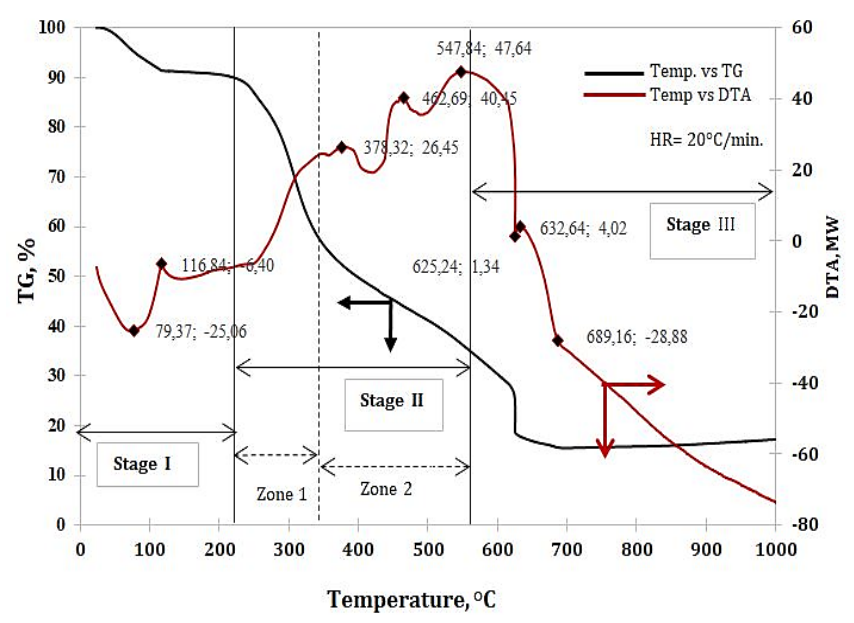

Fig. 3 TG-DTA curve at heating rate: $20^{\circ} \mathrm{C} / \mathrm{min}$

In Stage III, only non-condensable gases are released from char such as $\mathrm{CO}, \mathrm{CO}_{2}, \mathrm{H}_{2}$ and $\mathrm{CH}_{4}$ with very small weight loss. This may reflect that the heat required is relative only to the temperature rise, in which almost all volatile matter has been released in the pyrolysis zone. It is understandable because of the soft microalgae structure with relatively low lignin content (7.33 - $9.55 \mathrm{wt} \%)$, therefore volatile matter is easily removed from the tissues. Compared to hardwoods with large lignin content (25\%) and complex tissues, the thermal decomposition in hardwood at above $600^{\circ} \mathrm{C}$ still produces non-condensable gas, explaining why its weight loss is relatively large (810\%) (De Wild et al. 2011). To compare each peak in the overall heating rate tested, the same procedure at the 
heating rate $20^{\circ} \mathrm{C} / \mathrm{min}$ (Figure 3) was performed, resulting in the TG-DTA curve in Figure 4 and further listed in Table 4.

The division of the pyrolysis zone for other heating rates is done as in the heating rate of $20^{\circ} \mathrm{C} / \mathrm{min}$ (Figure 3 ), where the distribution of pyrolysis zone for all heating rates is presented in Table 3.

\section{Table 3}

The distribution of SPR pyrolysis zone for various heating rates on SPR thermal decomposition.

\begin{tabular}{ccc}
\hline $\begin{array}{c}\text { Heating rate, } \\
{ }^{\circ} \mathbf{C} / \mathbf{m i n}\end{array}$ & Zone 1 & Zone 2 \\
\hline 10 & $221-350$ & $351-615$ \\
20 & $231-350$ & $351-570$ \\
30 & $241-380$ & $381-585$ \\
40 & $251-380$ & $381-570$ \\
50 & $261-350$ & $351-600$ \\
\hline
\end{tabular}

The peaks in DTA curves represent the events of heat increase, both endothermically and exothermically. In Stage II, pyrolysis for each heating rate of 10,20 and $30^{\circ} \mathrm{C} / \mathrm{min}$ produces 3 peaks at a certain temperature, slightly higher than the 2 peaks for the heating rate of 40 and $50^{\circ} \mathrm{C} / \mathrm{min}$. The difference in the number of peaks can be ascribed by the amount of heat flowed into the process in every minute. At the heating rate of 40 and $50^{\circ} \mathrm{C} / \mathrm{min}$, the heat is relatively large if compared to the heating rate of 10,20 and $30^{\circ} \mathrm{C} / \mathrm{min}$. The heat requirement at these two heating rates is relatively sufficient for decomposition to occur at the beginning of pyrolysis, thus producing only 2 peaks. Furthermore, a positive peak value describes an exothermic process while a negative peak value describes an endothermic process. The endothermic and exothermic process occurs because of both the termination of low-energy bonding such as $\mathrm{C}-\mathrm{N}, \mathrm{N}-\mathrm{H}$, $\mathrm{C}-\mathrm{H}$ of proteins as well as of high-energy bonding such as $\mathrm{C}=\mathrm{C}, \mathrm{CH}, \mathrm{C}=\mathrm{N}, \mathrm{C}=\mathrm{O}, \mathrm{OH}$ and $\mathrm{O}=\mathrm{O}$ which are commonly found in carbohydrates.

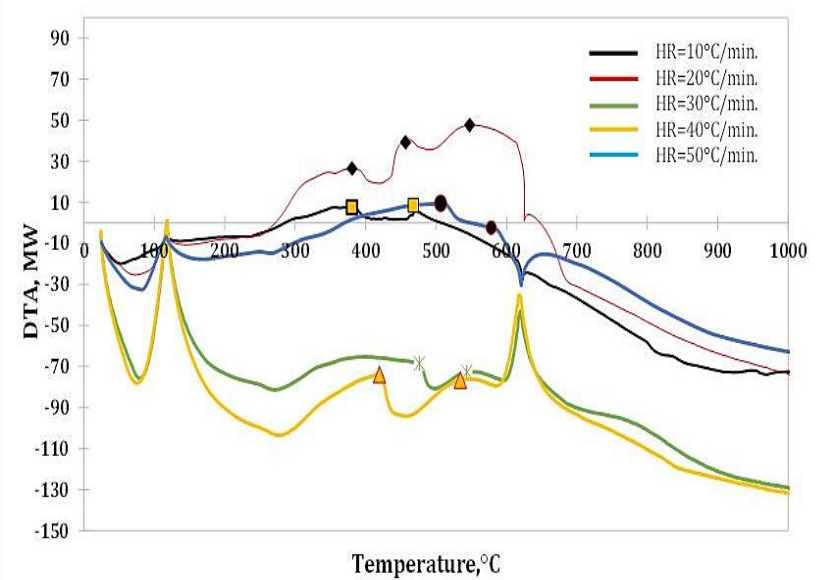

Fig. 4 The peaks on pyrolysis zone of DTA curve at the heating rate of $10,20,30,40$ and $50^{\circ} \mathrm{C} / \mathrm{min}$

Table 4

The peak on SPR pyrolysis zone and heat value for various heating rates

\begin{tabular}{ccccccc}
\hline \multicolumn{2}{l}{ Heating rate, ${ }^{\circ} \mathbf{C} / \mathbf{m i n}$} & $\mathbf{1 0}$ & $\mathbf{2 0}$ & $\mathbf{3 0}$ & $\mathbf{4 0}$ & $\mathbf{5 0}$ \\
& & & & & & \\
\multirow{2}{*}{ Peak 1 } & Temp. ${ }^{\circ} \mathrm{C}$ & 388.04 & 378.32 & 381.02 & 419.69 & 506.63 \\
& DTA, MW & 2.65 & 26.45 & -65.48 & -73.91 & 9.50 \\
\multirow{2}{*}{ Peak 2 } & & & & & \\
& Temp. ${ }^{\circ} \mathrm{C}$ & 467.96 & 462.69 & 476.40 & 534.57 & 578.38 \\
& DTA, MW & 8.63 & 40.45 & -68.48 & -76.61 & -2.34 \\
Peak 3 & Temp., ${ }^{\circ} \mathrm{C}$ & 614.70 & 547.84 & 550.21 & - & - \\
& DTA, MW & -20.79 & 47.64 & -76.08 & - & - \\
\hline
\end{tabular}

\subsubsection{TG-DTG curves}

The TG-DTG curve at the $50^{\circ} \mathrm{C} / \mathrm{min}$ heating rate is presented in Figure 5, where each peak in Stage II signifies the release of volatile matter at certain temperature and rate of weight loss. The 2 peaks at Zone I in DTG curve occur at 267.48 and $331.05^{\circ} \mathrm{C}$ with the weight loss rate of 10.72 and $26.18 \mathrm{~g} / \mathrm{min}$, respectively. While protein and carbohydrate decomposition occurs in this zone, lipid decomposition does not take place due to the notably low lipid content in the SPR (0.01\%wt). The second peak is the highest peak with a weight loss rate of $26.18 \mathrm{~g} / \mathrm{min}$ at $331.05^{\circ} \mathrm{C}$. Similar two peaks in Stage II were also obtained during thermal decomposition of Chlorella vulgaris, one peak in Zone I and one peak in Zone 2 (Wang et al. 2016).

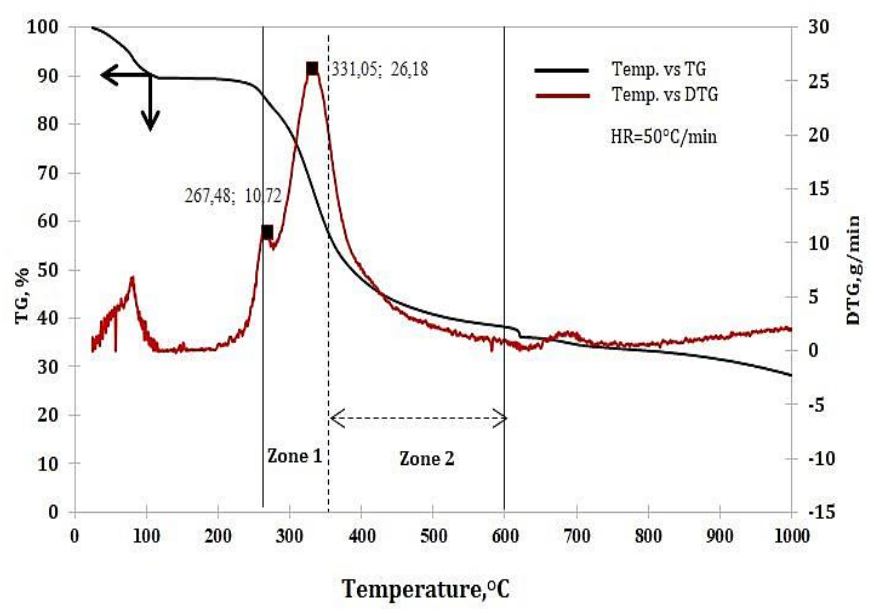

Fig. 5 TG-DTG curve at heating rate $50^{\circ} \mathrm{C} / \mathrm{min}$ 
Citation: Jamilatun, S., Budhijanto, Rochmadi, and Budiman, A. (2017) Thermal Decomposition and Kinetic Studies of Pyrolysis of Spirulina platensis Residue. Int. Journal of Renewable Energy Development, 6(3), 193-201, https://doi.org/10.14710/ijred.6.3.193-201

$\mathrm{P}$ a g e | 198

The difference in peak temperature can be ascribed to the difference in heating rates as well as the composition of $\mathrm{O}$ content, protein, carbohydrate, and lipid. The peaks from DTG curve with the heating rate of $10,20,30,40$ and $50^{\circ} \mathrm{C} / \mathrm{min}$ can be seen in Figure 6 and are listed in Table 5.

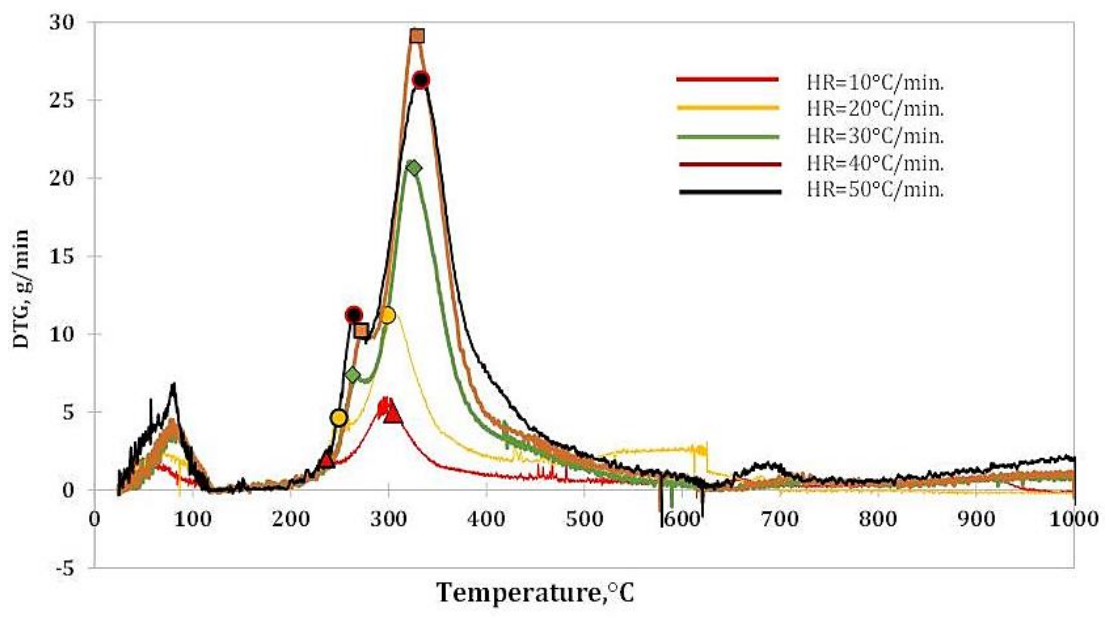

Fig. 6 The peaks on pyrolysis zone of DTG curve at the heating rate of $10,20,30,40$ and $50^{\circ} \mathrm{C} / \mathrm{min}$

Table 5

The peaks on DTG curve at various SPR pyrolysis heating rates

\begin{tabular}{ccccccc}
\hline \multicolumn{2}{c}{ Heating rate, ${ }^{\circ} \mathbf{C} / \mathbf{m i n}$} & $\mathbf{1 0}$ & $\mathbf{2 0}$ & $\mathbf{3 0}$ & $\mathbf{4 0}$ & $\mathbf{5 0}$ \\
\hline \multirow{2}{*}{ Peak 1 } & Temp., ${ }^{\circ} \mathrm{C}$ & $236.35 \pm 2.36$ & $249.12 \pm 2.49$ & $253.70 \pm 0.54$ & $272.15 \pm 2.72$ & $267.48 \pm 2.67$ \\
& DTG, g/min & $2.02 \pm 0.02$ & $4.64 \pm 0.05$ & $7.29 \pm 0.07$ & $10.22 \pm 0.10$ & $10.72 \pm 0.11$ \\
\multirow{2}{*}{ Peak 2 } & Temp., ${ }^{\circ} \mathrm{C}$ & $304.67 \pm 3.04$ & $288.45 \pm 2.89$ & $311.66 \pm 3.12$ & $329.47 \pm 3.29$ & $331.05 \pm 3.31$ \\
& DTG, g/min & $4.97 \pm 0.05$ & $11.10 \pm 0.11$ & $20.94 \pm 0.21$ & $29.12 \pm 0.29$ & $26.18 \pm 0.26$ \\
\hline
\end{tabular}

Figure 6 illustrates the DTG curve for heating rate from 10 to $50^{\circ} \mathrm{C} / \mathrm{min}$. The rates of weight loss at each peak in the curve are listed in Table 5 . The first peak at the lowest temperature occurs during the lowest heating rate $\left(10^{\circ} \mathrm{C} / \mathrm{min}\right)$ at $236.35^{\circ} \mathrm{C}$ with weight loss rate of $2.02 \mathrm{~g} / \mathrm{min}$. Furthermore, with the increase of the heating rate the first peak temperature also increases regularly, i.e., for heating rate of $20,30,40$ and $50^{\circ} \mathrm{C} / \mathrm{min}$, the first peak occurs at $249.12,253.70$, 272.15 and $276.48^{\circ} \mathrm{C}$, respectively. It is deduced that the increase of the heating rate does not affect the temperature of the second peak, as it is seen that the temperature at the second peak fluctuates. Although the initial temperature peak appears to rise regularly with the increase of heating rate, the increase of heating rate actually results in shorter initial peak, i.e., for heating rate $10,20,30,40$ and $50^{\circ} \mathrm{C} / \mathrm{min}$, the first peak occurs in $27.17,17.33,19.1,17.67$, and 11 minutes. From the five tested heating rates, the highest peak found occurs during the heating rate $40^{\circ} \mathrm{C} / \mathrm{min}$ at $329.47^{\circ} \mathrm{C}$ with a weight loss rate of 29.12 $\mathrm{g} / \mathrm{min}$. It is at this peak that the most rapid and large volatile matter release occurred, resulting in a large heat requirement.

\subsection{Kinetics}

The reaction kinetic for the one-step global model can be derived from Equation (3), where the value of collision factor (A) and activation energy (Ea) can be calculated using Equations (5)-(8) with SSE calculation in Matlab using Equation (9). The calculated values of $\mathrm{A}, \mathrm{Ea}$, and $\mathrm{k}$ for each heating rate in Zone 1 are presented in Table 6 and Zone 2 in Table 7. Equation 7 is evaluated, where the pyrolysis temperature $(\mathrm{T})$ is influenced by heating rate $(B)$ and time $(\mathrm{t})$. The relationship between pyrolysis time and temperature $\left((\mathrm{T})_{\text {calculated }}\right.$ and $\left.(\mathrm{T})_{\text {data }}\right)$ in Zone 1 and 2 are presented in Fig. 7. For both zones, it can be seen that the $(\mathrm{T})_{\text {calculated }}$ and $(\mathrm{T})_{\text {data }}$ value coincide with one another.

Furthermore, the calculated conversion $(\mathrm{X})_{\text {calculated }}$ from Eq. (6) and the conversion observed from the experiment $(\mathrm{X})_{\text {data }}$ are employed to calculate Sum of squared errors (SSE). The relationship of both of these conversions with time can be seen in Fig. 8. In Fig. 7 and 8 , the heating rate of $20^{\circ} \mathrm{C} / \mathrm{min}$ is selected because it produces the smallest SSE value of 0.0506 for Zone 1 and 0.0427 for Zone 2. The SSE values between $(\mathrm{X})_{\text {calculated }}$ and $(\mathrm{X})_{\text {data }}$ indicate that one-step global 
model can be used for the calculation of Ea and $\mathrm{k}$ at a certain temperature range. The SSE value for the other heating rates $\left(10,30,40\right.$ and $\left.50^{\circ} \mathrm{C} / \mathrm{min}\right)$ was investigated in the same way as the heating rate of $20^{\circ} \mathrm{C} / \mathrm{min}$, and the results are set forth in Table 6 and

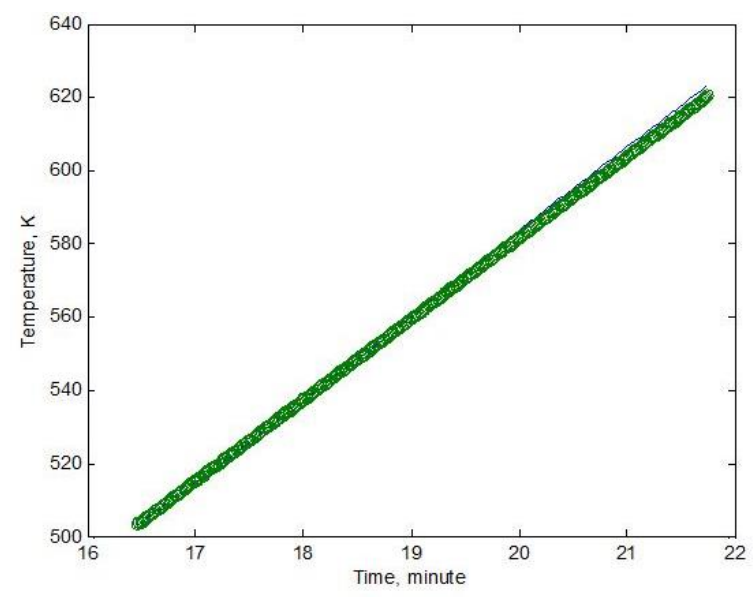

(7a)
Table 7. It appears that the SSE value for all heating rates is relatively small.

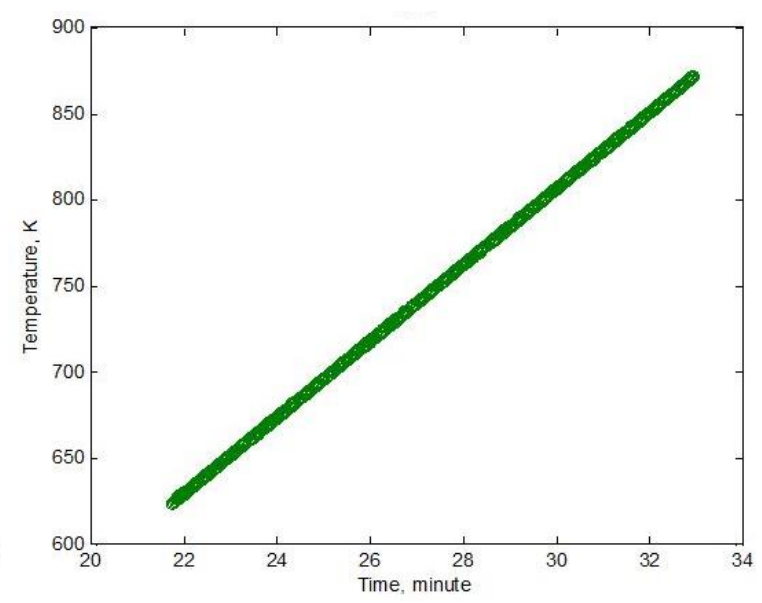

(7b)

Fig. 7 The relationship between time and pyrolysis temperature for heating rate of $20^{\circ} \mathrm{C} / \mathrm{min}$ in (a) Zone 1 and (b) Zone 2

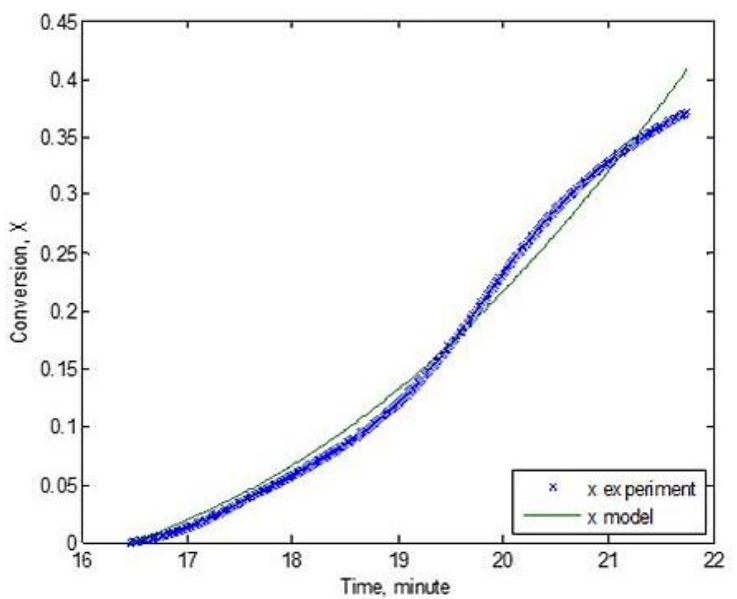

(8a)

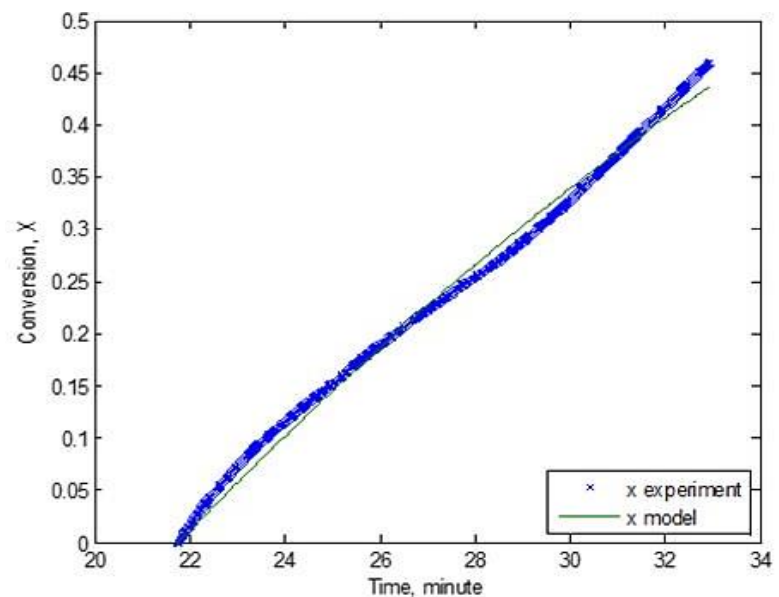

$(8 b)$

Fig. 8 The relationship between time and conversion for heating rate of $20^{\circ} \mathrm{C} / \mathrm{min}$ in (a) Zone 1 ; (b) Zone 2

The calculation results for all heating rate show that the increase in heating rate affects the value of Ea and $\mathrm{A}$. The pyrolysis temperature range of each heating rate is not similar, possibly due to typical SPR characteristics when pyrolysis involves a very complex reaction simultaneously.

The global one-step model equation applies only to a certain temperature range and can not be used for the overall pyrolysis temperature range. It is necessary to divide the pyrolysis zone by looking at the tendency of TG curve or weight loss curve. Figure 9 shows the relation between the rate of reaction constants $(\mathrm{k})$ and reaction temperature at various heating rates in Zone 1 and Zone 2. The slope of the TG curve in Zone 1 is very steep for all heating rates.
From Table 6 it can be deduced that for heating rate $10,20,30,40$ and $50^{\circ} \mathrm{C} / \mathrm{min}$ with the reaction order $\mathrm{n}=1$, activation energy $\left(\mathrm{E}_{\mathrm{a}}\right)$ value tends to increase with the increase of heating rate. A higher heating rate value will promote a higher A value, hence increasing Ea as well. The A and Ea value increase regularly but start to be constant as it reaches the heating rate of 40 $50^{\circ} \mathrm{C} / \mathrm{min}$. Thus, the recommended heating rate for the optimum plant design is at $40-50^{\circ} \mathrm{C} / \mathrm{min}$. Furthermore, it can be concluded from SPR pyrolysis results that with the heating rate $10-50^{\circ} \mathrm{C} / \mathrm{min}$, Ea for protein and carbohydrate decomposition lies within 35.46-47.89 $\mathrm{KJ} / \mathrm{mol}$ with reaction rate constant $(\mathrm{k})$ value lies in the range of (0.0168-0.1021) - (0.0995-0.4691) sec $\mathrm{se}^{-1}$. The value of Arrhenius (A) factor, Ea and $\mathrm{k}$ for various heating rate in Zone 2 are presented in Table 7. 
Citation: Jamilatun, S., Budhijanto, Rochmadi, and Budiman, A. (2017) Thermal Decomposition and Kinetic Studies of Pyrolysis of Spirulina platensis Residue. Int. Journal of Renewable Energy Development, 6(3), 193-201, https://doi.org/10.14710/ijred.6.3.193-201

$\mathrm{P}$ a g e | 200

Table 6

Reaction kinetic parameters of the SPR for Zone I

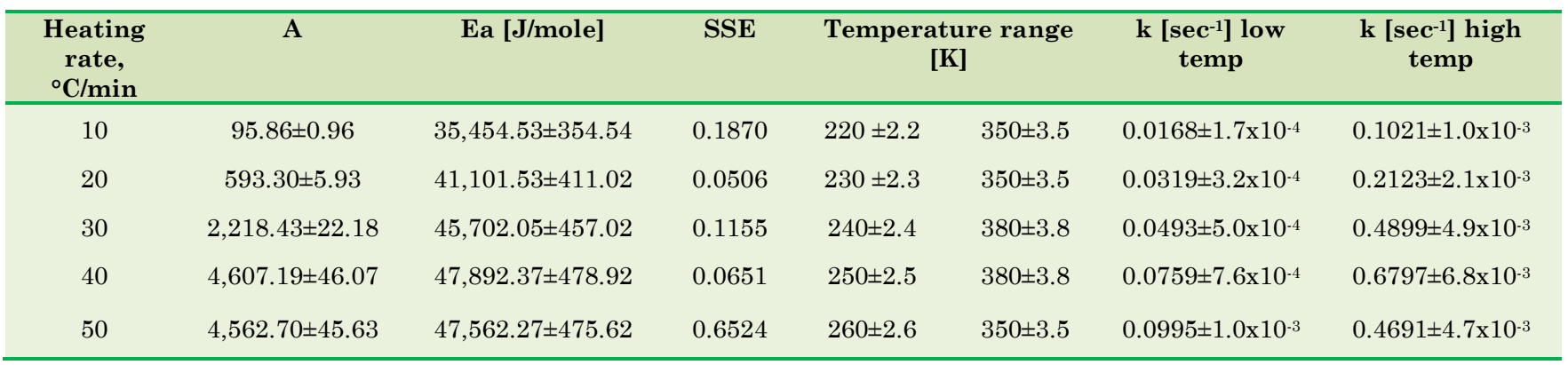

Tabel 7

Reaction kinetic parameters of the SPR for Zone 2

\begin{tabular}{|c|c|c|c|c|c|c|c|}
\hline $\begin{array}{l}\text { Heating, } \\
\text { rate } \\
{ }^{\circ} \mathrm{C} / \mathrm{min}\end{array}$ & A & Ea, J/mole & SSE & Temper & re range & $\begin{array}{c}\left.\text { k [sec }{ }^{-1}\right] \text { low } \\
\text { temp. }\end{array}$ & $\begin{array}{c}\left.\text { k [sec }{ }^{-1}\right] \text { high } \\
\text { temp. }\end{array}$ \\
\hline 10 & $0.0204 \pm 2 \times 10^{-4}$ & $0.1428 \pm 1.4 \times 10^{-3}$ & 0.3472 & $351 \pm 3.5$ & $615 \pm 6.2$ & $0.0203 \pm 2 \times 10^{-4}$ & $0.0203 \pm 2 \times 10^{-4}$ \\
\hline 20 & $0.0489 \pm 5 \times 10^{-4}$ & $0.1240 \pm 1.2 \times 10^{-3}$ & 0.0427 & $351 \pm 3.5$ & $570 \pm 5.7$ & $0.0489 \pm 4.9 \times 10^{-4}$ & $0.0489 \pm 4.9 \times 10^{-4}$ \\
\hline 30 & $0.0693 \pm 7 \times 10^{-4}$ & $0.0179 \pm 1.8 \times 10^{-3}$ & 0.3389 & $381 \pm 3.8$ & $585 \pm 5.9$ & $0.0693 \pm 6.9 \times 10^{-4}$ & $0.0693 \pm 6.9 \times 10^{-4}$ \\
\hline 40 & $0.1321 \pm 1 \times 10^{-4}$ & $0.0100 \pm 1 \times 10^{-3}$ & 0.9220 & $381 \pm 3.8$ & $570 \pm 5.7$ & $0.1321 \pm 1.3 \times 10^{-3}$ & $0.1321 \pm 1.3 \times 10^{-3}$ \\
\hline 50 & $0.1278 \pm 1 \times 10^{-4}$ & $0.0096 \pm 1 \times 10^{-4}$ & 0.8811 & $351 \pm 3.5$ & $600 \pm 6$ & $0.1278 \pm 1.3 \times 10^{-3}$ & $0.1278 \pm 1.3 \times 10^{-3}$ \\
\hline
\end{tabular}

From Table 7 it appears that the A value is relatively small and rises regularly with an increase in the heating rate to $40^{\circ} \mathrm{C} / \mathrm{min}$. On the other hand, Ea value decreases regularly with the increase of heating rate. This indicates that in Zone 2 the release of volatile matter is not as large as in Zone 1 , as it is characterised by weight loss rate with peaks appearing only in Zone 1 . This is different from zone 2 where pyrolysis is stable with the slope of the TG curve tends to be flat. The activation energy for heating rate 10, 20, 30, 40 and $50^{\circ} \mathrm{C} / \mathrm{min}$ respectively is $0.0001428,0.0001240$, $0.0000179,0.0000100$ and $0.0000096 \mathrm{KJ} / \mathrm{mol}$, while the $\mathrm{k}$ value is $0.0204,0.00489,0.0693,0.1321$ and 0.1278 $\mathrm{sec}^{-1}$, respectively.

The effect of the heating rate on the value of $\mathrm{k}$ for zone 1 and zone 2 is shown in Figure 9. It is seen that in Zone 1 for each heating rate, the $\mathrm{k}$ value increases sharply along with the rise in temperature, where it is influenced by temperature, Ea and A. For zone 2 on various heating rate, the effect of temperature rise to $\mathrm{k}$ is relatively small as the $\mathrm{k}$ value for each heating rate is constant, as depicted in Fig. 9 with a flat line.

At the same heating rate of $10^{\circ} \mathrm{C} / \mathrm{min}$, the Ea value of SPR pyrolysis $(35.45 \mathrm{~kJ} / \mathrm{mol})$ in Zone 1 and $(0.0001428 \mathrm{~kJ} / \mathrm{mol})$ in Zone 2 are much lower than the Ea value for Chlorella vulgaris both in Zone I (51 $\mathrm{KJ} / \mathrm{mol})$ and Zone $2(1.64 \mathrm{KJ} / \mathrm{mol})$ in Zone 2. The significant difference in Ea in Zone 1 is due to the different protein, carbohydrate and lipid contents. Whereas in Zone 2, the very small Ea value for SPR indicates that there is no lipid decomposition because of its very small lipid content (0.01 wt.\%). This is different for Zone 2 for Chlorella vulgaris, where the Ea value of $1.64 \mathrm{KJ} / \mathrm{mol}$ indicates that lipid decomposition still occurs in Zone 2.

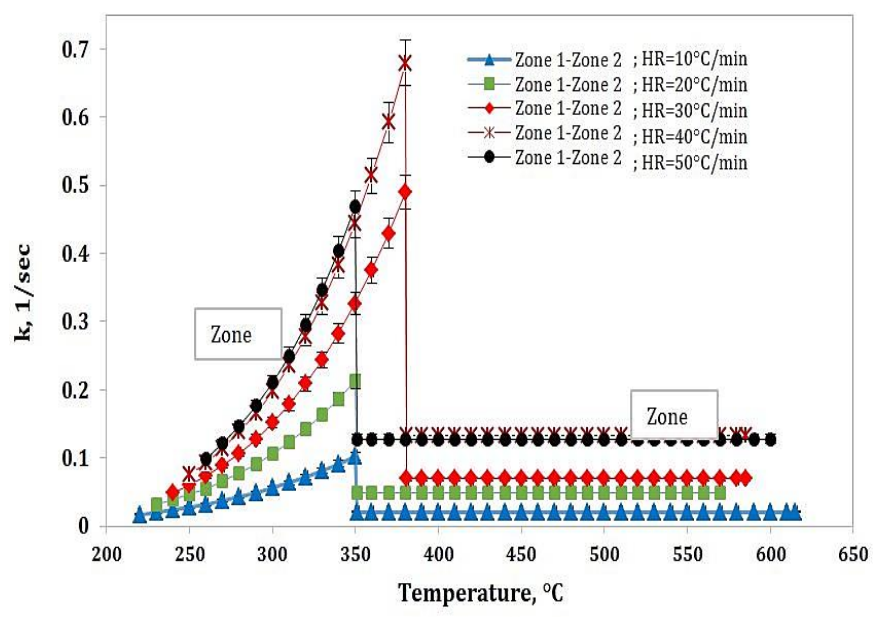

Fig. 9 The relation between the rate of reaction constants $(\mathrm{k})$ and reaction temperature at various heating rates in Zone 1 and Zone

\section{Conclusion}

Spirulina platensis residue (SPR) with a high protein and carbohydrate content exhibits the potential to be processed into an energy source with pyrolysis. However, it is necessary to understand the thermal decomposition and kinetics data of the pyrolysis for the reactor design. In this work, a TG-DTA-DTG analysis has been developed to investigate the characteristics of 
pyrolysis, activation energy (Ea) and reaction rate constant (k) for each heating rate. One step global model is suitable for all heating rate at certain temperature range for zone 1 and 2 . In Zone 1 , the bigger the heating rate the bigger $\mathrm{Ea}$ and $\mathrm{k}$ values, whereas for zone 2 the bigger the heating rate the smaller the Ea and $\mathrm{k}$ value. Thermal decomposition in Stage I occurs in endothermic condition. On the other hand, in Stage II thermal decomposition is exothermic for heating rate 10,20 and $50^{\circ} \mathrm{C} / \mathrm{min}$ and endothermic for the heating rate of 30 and $40^{\circ} \mathrm{C} / \mathrm{min}$. The gasification process occurs in Stage III in endothermic condition. From the DTA curve, 3 peaks were obtained for heating rates 10,20 and $30^{\circ} \mathrm{C} / \mathrm{min}$ and 2 peaks for heating rates 40 and $50^{\circ} \mathrm{C} / \mathrm{min}$ in the pyrolysis zone. For all heating rate, 2 peaks were obtained from DTG curve at zone 1 with the highest peak found for heating rate $40^{\circ} \mathrm{C} / \mathrm{min}$, i.e. at $329.47^{\circ} \mathrm{C}$ with weight loss rate of $29.12 \mathrm{~g} / \mathrm{min}$.

\section{Acknowledgments}

The authors gratefully thank Faith and the Directorate General of Higher Education, Ministry of Research Technology and Higher Education, the Republic of Indonesia for the support and funding in the scheme of "International Research Collaboration and Scientific Publication" under the supervision of Research Institutions and Community Service, Gadjah Mada University, Yogyakarta, Indonesia. The authors are also thankful for Muhamad Hartono and Takdir for his help during the manuscript preparation.

\section{References}

Agrawal, A. \& Chakraborty, S. (2013) A kinetic study of pyrolysis and combustion of microalgae Chlorella vulgaris using thermo-gravimetric analysis. Bioresour. Technol., 128, 72-80.

Ananda, V., Sunjeeva, V. \& Vinua, R. (2016) Catalytic fast pyrolysis of Arthrospira platensis (spirulina) algae using zeolites. J. Anal. Appl. Pyrolysis, 118, 298-307.

Chisti, Y. (2008) Biodiesel from microalgae beats bioethanol. Trends. Biotechnol., $26, \quad 126 \quad$ - 131. doi:10.1016/j.tibtech.2007.12.002.

Chaiwong, K., Kiatsiriroat, T., Vorayos, N. \& Thararax, C. (2013) Study of bio-oil and bio-char production from algae by slow pyrolysis. Biomass Bioenerg., 56, 600-606.

Ceylan, S., Topcu, Y. \& Ceylan, Z. (2014) Thermal behaviour and kinetics of algae Polysiphonia elongata biomass during pyrolysis. Bioresour. Technol., 171, 193-198.

Chen, W.H., Lin, B-J., Huang, M-Y. \& Chang, J-S. (2015) Thermochemical conversion of microalgal biomass into biofuels: A review. Bioresour. Technol., 184, 314-327.

Dragone, G., Fernandes, B., Vicente, A. \& Teixeira, J.A. (2010) Third generation biofuels from microalgae. In: Vilas AM, editor. Current research, technology and education topics in applied microbiology and microbial biotechnology. Badajoz: Formatex Research Center; 1355-66.

De Wild, P.J., Reith, H. \& Heeres, H.J. (2011) Biomass pyrolysis for chemicals. Biofuels, 2 (2), $185-208$.

Daniyanto, Sutijan, Deendarlianto, \& Budiman, A. (2016) Reaction kinetic of pyrolysis in mechanism of pyrolysisgasification process of dry torrified-sugarcane bagasse. ARPN
Journal of Engineering and Applied Sciences, 11, Issue 16, 9974-9980.

El-Sayed, S.A. \& Mostafa, M.E. (2014) Pyrolysis characteristics and kinetic parameters determination of biomass fuel powders by differential thermal gravimetric analysis (TGA/DTG). Energ. Conversion and Manag, 85, 165-172.

Hadiyanto, Widayat \& Kumoro, A.C. (2012) Potency of microalgae as biodiesel source in Indonesia. Int. Journal of Renewable Energy Development, 1, 23-27.

Hadiyanto H., Christwardana, M. \& Soetri, D. (2013) Phytoremediations of palm oil mill effluent (POME) by using aquatic plants and microalgae for biomass production. Journal of Environmental and Technology. ISSN 19947887/DOI:10.3923/jest.2013.

Hu, M., Chen, Z., Guo, D., Liu, C., Xiao, B., Hu, Z. \& Liu, S. (2015) Thermogravimetric study on pyrolysis kinetics of Chlorella pyrenoidosa and bloom-forming cyanobacteria. Bioresour Technol., 177, 41-50.

Lia, J., Wanga, G., Wanga, Z., Zhanga, L., Wang, C. \& Yang, Z. (2013) Conversion of Enteromorpha prolifera to high-quality liquid oil viadeoxy-liquefaction. J. Anal. Appl. Pyrolysis, 104, 494-501.

Li, S., Ma, X., Liu, G. \& Guo, M. (2016) A TG-FTIR investigation to the co-pyrolysis of oil shale with coal. J. Anal. Appl. Pyrolysis, 120, 540-548.

Ojolo, S.J., Oshekub, C.A. \& Sobamowoa, M.G. (2013) Analytical investigations of kinetic and heat transfer in slow pyrolysis of a biomass particle. Int. Journal of Renewable Energy Development, 2 (2), 105-115.

Prakash, N. \& Karunanithi, T. (2008) Kinetic modeling in biomass pyrolysis - A Review. J. Appl. Sci. Res., 4(12), 16271636.

Pratama, N.N. \& Saptoadi, H. (2014) Characteristics of waste plastics pyrolytic oil and its applications as alternative fuel on our cylinder diesel engines. Int. Journal of Renewable Energy Development, 3 (1), 13-20

Sunarno, Herman, S., Rochmadi, Mulyono, P. \& Budiman, A. (2017) Effect of Support on Catalytic Cracking of Bio-Oil over Ni/Silica-Alumina. AIP Conference Proceedings 1823, 020089; doi: 10.1063/1.4978162.

Suganya, T., Varman, M., Masjuki, H.H. \& Renganathan, S. (2016) Macroalgae and microalgae as a potential source for commercial applications along with biofuels production: A biorefinery approach. Renew Sust Energ Rev, 55, 909-941.

Wijffels, R.H., Barbosa, M.J. \& Eppink, M.H.M. (2010) Microalgae for the production of bulk chemicals and biofuels. Biofuels Bioproducts \& Biorefining-Biofpr. 4(3), 287-295.

Widiyannita, A.M., Cahyono, R.B., Budiman, Sutijan, A. \& Akiyama, T. (2015) Study of pyrolysis of ulin wood residues. AIP Conference Proceedings 1755, 050004.

Wang, X., Hu, M., Hu, W., Chen, Z., Liu, S., Hu, Z. \& Xiao, B. (2016) Thermogravimetric kinetic study of agricultural residue biomass pyrolysis based on combined kinetics. Bioresour. Technol., 219, 510-52.

Wicakso, D.R., Sutijan, Rochmadi, \& Budiman, A. (2017) Study of catalytic upgrading of biomass tars using Indonesian iron ore. AIP Conference Proceedings 1823, 020094; doi: $10.1063 / 1.4978167$ 